Всрнік О. А.,

кандидат філологічних наук, доцент, доцент кафедри світової літератури та російського мовознавства Луганський національний університет імені Тараса Шевченка (м. Старобільськ)

\title{
СОЦІАЛІСТИЧНИЙ РЕАЛІЗМ \\ В ПОЕМІ Є. ПОЛОНСЬКОЇ «ПОРТРЕТ»
}

С. Полонська в поемі «Портрет» створила образ Т. Шевченка, представила власну рецепиію долі й творчості поета. Зміст твору свідчить про глибоке знання російською поетесою не тільки долі Кобзаря, але й культури, історї Украӥни. Вона активно використовує українські слова та діалектизми. Образ Т. Шевченко репрезентує особисте, материнське ставлення $Є$. Полонської до українського поета. Незважаючи на сочреалізм твору, російській поетесі вдалося уникнути монументальності в зображенні Т. Шевченка, читач разом з автором співчуває головному герою поеми.

Ключові слова: образ, поема, рецепчія, репрезентація, сочіалістичний реалізм

Е. Полонская в поеме «Портрет» создала образ Т. Шевченко, представила собственную рецепцию судьбы и творчества поэта. Содержание произведения свидетельствует о глубоком знании русской поэтессой не только судьбы Кобзаря, но и культуры, истории Украины. Она активно использует в произведении украинские слова и диалектизмы. Образ Т. Шевченко репрезентует личностное, материнское отночение Е. Полонской к судьбе украинского поэта. Несмотря на сочреализм произведения, русской поэтессе удалось избежать монументальности в изображении Т. Шевченко, читатель вместе с автором сочувствует главному герою поэмы.

Ключевые слова: образ, поэма, рецепџия, репрезентация, социалистический реализм.

E. Polonskaya has created the image of T. Shevchenko in poem "Portrait». She presented her own reception of destiny and works of the poet. The content of the work shows deep knowledge of the Russian poetess not only about the fate of the Bard, but also about the culture and the history of Ukraine. She widely uses Ukrainian words and dialecticisms in the poem. The Image of Taras Shevchenko represents personal, maternal attitude of E. Polonskaya to the fate of Ukrainian poet. Despite the socialist realism of works, Russian poetess avoided monumentality in the image of $T$. Shevchenko, the reader together with the author sympathize with the protagonist of the poem.

Keywords: image, poem, reception, representation, socialist realism.

У 1939 році Є. Полонська осмислює долю Тараса Шевченка в поемі «Портрет». Інтерес автора до історико-біографічного жанру, за словами Б. Фрезінского, свідчить про внутрішню еміграцію поетеси, про іiі бажання уникнути звернення до сучасності: «Зазвичай $і$ особливо в післявоєнний час в цей сумнівний, зокрема для поезії, жанр йшли ті, хто не хотів і не міг писати про реальну сучасність» [Фрезинский 2010:66-67]. Ця поема є прикладом соцреалізму Є. Полонської, оскільки про це свідчать багато складових іiі поетики. 3 першого погляду здається дивним, чому авторка, яка на початку 
творчого шляху вважала себе ученицею та послідовницею М. Гумільова, у 1920-ті роки належала до літературної групи «Серапіонови брати», яка, як відомо, заперечувала ідеологію в літературі, висуваючи на перший план художні властивості твору, звернулась до соцреалістичного канону. До 1930 року поетеса видала три збірки: «Знаменья» (1921), «Под каменным дождем» (1923), «Упрямый календарь. Стихотворения и поэмы» (1924-1927), причому кожна 3 них містила твори про революцію, сучасність; від збірки до збірки у віршах посилюється ідеологічна складова, яка в кінцевому підсумку закономірно привела автора до активного вияву соцреалістичної домінанти в піi творчості. Цей свідомий авторський вибір обумовлений, у першу чергу, необхідністю адаптуватися до реалій радянського життя. На жаль, до сьогодні ще немає розвідок творчості Є. Полонської (виняток - біографічне дослідження Б. Фрезинського), особливо соцреалістичного канону ii творів, а поема про Т. Шевченка «Портрет» ще ніколи не ставала предметом дослідження науковців. Усе це обумовлює актуальність статті.

Мета статті - дослідити втілення соцреалізму в поемі Є. Полонської «Портрет».

3 1930-х років Є. Полонська присвячує себе в основному перекладацькій роботі, справедливо вважаючи, що це захистить їі від сталінського терору, який торкнувся близьких поетеси. Б. Фрезинський, який відкрив сучасним читачам іiі мемуари, пише про те, що починаючи 3 тридцятих років письменниця була смертельно налякана, тому «міцно лягла на дно», вибравши малопомітну літературну роботу: писала нариси про працьовитих жінок, перекладала революційних поетів заходу й поетів національних республік ... вона завжди воліла жити поза світлом юпітерів [Фрезинский 2010:56]. Одним із доказів штучності соцреалістичного канону в поезії Полонської можна назвати відгук М. Гутнера на книгу ii вибраних творів «Роки» (1935). Критик, аналізуючи збірник в контексті інших книг поетеси, писав, що «громадянський віри С. Полонської не має нічого спільного з поезією револючійних демократів; за своїм нарочито-архаӥчним обличчям він близький до політичной лірики 
Тютечева <..> Полонська ... не могла по-справжньому знайти своєї поетичної теми в гущуавині повсякденної радянської дійсності» [Полонская 2010:61]. Ця розгромна стаття в газеті «Літературний Ленінград» сприяла творчому «переродженню» Є. Полонської, пошуку нових шляхів, при цьому «віриі тільки втрачали й у формі, і в змісті, ставали радянськими, тобто по сутініякими. Зрозуміло, цее йило в такт потоку політичних подій», - вказує Б. Фрезинський [Фрезинский 2010:61]. «Радянське» у іiі творах також пояснюється приналежністю (за класифікацією Т. Круглової) до авторського типу покоління 1890-х років народження, яке «несло в собі художній та світоглядний габітус діячів срібного століття. Це покоління реалізовувалося на перетині двох векторів, одним з яких залишалася тенденція автономного художнього розвитку, вирішення внутрішньо художніх завдань, а другим був вектор соціуму - усе більш сильного тиску гетерономного поля. Творчі результати були здебільшого рівнодіючої двох векторів» [Круглова 2005:27].

Очевидно, що Є. Полонська намагалася зрозуміти закономірності побудови «радянських» творів, і багато в чому цьому сприяв творчий досвід, здобутий в групі «Серапіонови брати», оскільки «серапіони» велике значення приділяли ретельній роботі над словом, кожною складовою твору. Ці «вправи» поетеси, що увійшли до книги «Нові вірші 1932-1936», радянський критик Л. Длугач справедливо назвав «слабкими» [Длугач 1937:5]. Б. Фрезинський уважає, що для Є. Полонської, яка тоді вирішила остаточно піти з медицини й «стати радянським поетом, була потрібна «чимала «перебудова зусиль $і$ волі» [Фрезинский 2010:56]. Усе це пояснюється зрозумілим страхом перед незатребуваністю, несучасністю, втратою власного читача.

Саме в такій складній художній та світоглядній ситуації Є. Полонська береться за створення поеми про долю Тараса Шевченка. Її твір «Портрет» можна назвати відображенням, за визначенням Т. Круглової, соцреалістичної «поетики художнього компромісу», для якого характерні такі особливості: «домінанта компіляції як способу організації тексту; відсутність дистанційованої гри з уже створеними кимось прийомами; вибір жанрів, що 
дозволяють комбінувати міфологічне й реалістичне; здатність змінюватися згідно естетичним запитам часу; установка на актуальний успіх в адресата й влади; вирівнювання рівнів адресата й автора; цінність майстерності; ідеологічна нейтральність; традиціоналістська позиція у ставленні до художньої мови [Круглова 2005:28].

Композиційною основою поеми автор обрала історію легендарного портрета В. Жуковського, створеного К. Брюлловим для того, щоб викупити T. Шевченка 3 кріпацтва. Таким чином, історія створення картини дає Є. Полонській можливість відтворити основні моменти життя поета (стосунки 3 П. Енгельгардтом, знайомство з К. Брюлловим та I. Сошенко), його душевні переживання, представити власну рецепцію творчості Т. Шевченка.

Перша частина поеми емоційно розкриває жахи кріпацтва, безправного становища селянства, наголошує на аморальності рабства. Цьому багато в чому сприяє вживання займенника «ти», який так само допомагає читачу відчути моральні страждання Т. Шевченка:

Как страшно знать, что ты бесправен,

Что тыл лищь вещь в чужсой горсти.

Что можно взять тебя, оставить,

Избить, унизить, увезти [Полонская 1940:56].

Разом 3 тим у цій строфі відчувається й той політичний підтекст, i соціалістичний пафос, які були характерні для часу створення поеми (1939 рік). Працю Є. Полонська називає єдиною відрадою ліричного героя, соціальна несправедливість нівелює його творчі здобутки (тут пригадується гасло-заклик Максима Горького кінця 1920-х років про те, що основним предметом зображення радянського автора повинна бути праця):

Твой труд, одну твою отраду

И ту опошлят, оплюют

Тупой насмешки черным ядом.

Звернемо увагу на внутрішній монолог Василя Жуковського, його роздуми про власну долю, про принизливу роль придворного поета:

В игре интриг, в борьбе враждебных партий 
Заглохнет звук нелицемерных слов.

Судьба России брошена на карту.

Он не игрок - он иут у игроков.

С ним милостивы до поры, до срока...

Сегодня приласкают, завтра - нет...

Он пишет назидательные строки.

Ну что ж, и в Веймаре придворнылй жил поэт.

Надень колпак, намажь лице мукою!

Наивных фрейлин весели.

Певец Светланы, ты искал покоя!

Притворствуй, раболепствуй и юли [Полонская 1940:69].

Авторська рецепція В. Жуковського, на нашу думку, так само, як і ліричні відступи, має ідеологічний підтекст, обумовлений часом створення поеми, коли пафосом неприйняття монархії і класовою ненавистю пройняти всі твори радянського мистецтва. Як уже зазначалося, в тексті безліч таких яскравих ідеологічних моментів, які свідчать про приналежність твору саме до радянської літератури, до соцреалізму.

В. Жуковський розмірковує про необхідність порятунку декабристів (тут автор використовує пушкінську цитату: «Во глубине сибирских руд / Хранят герои гордое молчанье») і про те, що він нічого не може змінити в їхній долі. Звернемо увагу на лексику, стиль цього уривка, вони розмовні, просторічні, явно розраховані на широкі верстви малоосвіченого читача. Тому таке слововживання також обумовлено приналежністю поеми до соцреалізму i орієнтацією на відповідне коло читачів: «Был разговор сегодня с государем, / Головомойка, прощ⿻е говоря. / Через цุаревича он за друзей опальных / У государя милости просил» [Полонская 1940:68]. Стилістичні особливості поеми обумовлені особливою роллю адресата, який «в сощреалістичній дискурсі виступає як авторитетний представник соичуму, перед яким час від часу зобов'язаний звітувати художник, як експерт художньої якості $і$ суддя $<\ldots>$ Сочреалістичний дискурс орієнтується на створення «народної 
культури», в якій відмінність елітарної та масової культури стане несуттєвим» [Круглова 2005:27]. У даному випадку поема Є. Полонскої відповідає завданню соцреалістичному канону.

У фіналі поеми поетеса знову вдається до прийому монтажа, з’єднавши в одній частині дві сцени - розіграш портрету в лотерею і його знищення. Портрет В. Жуковського, написаний 3 «великой жалостью и яростью безмерной», міг би розповісти, «как во дворицовом зале / Меж дня и вечера, в интимный час, / Его в игру смешную разыграли, И ставкой лотереи был Тарас. / Был поднесен портрет императрице / Из прусских, толь чувствительных принцесс / И мог бы годы долгие храниться / Средь сувениров ... если б не исчез» [Полонская 1940:76]. Друга частина фіналу відтворює напружену атмосферу в палаці, коли «йарь был ... придирчиво жестоким, / Царища мучилась припадком головным, / А челядь бледная, дрожа, шептала строки, / Написанные бывщим крепостным». Полонська, прагнучи осмислити значення шевченківської епіграми для цุарської сім’ї, бачить в ній знак майбутньої революиї ХХ століття: «Как будто вдруг в дворцуовый вечный праздник / Ворвался, словно гром грядущчий век». Фінальні рядки поеми знову повертають читача до легендарного портрету, який став символом кращого, що може бути в людині: гуманізму, співчуття, душевної щедрості; разом з тим доля картини демонструє неможливість існування гуманізму в царській Росії:

Портрет исчез. Он был подвергнут казни,

Сожжен иль выслан, словно человек.

Таким чином, у поемі «Портрет» Є. Полонська створила образ Т. Шевченка, представила власну рецепцію долі й творчості поета. Соцреалізм твору є відбитком тієї ідеології, до якої поетеса намагалася пристосуватись. Разом $з$ тим, ми вважаємо, що зміст твору свідчить про глибоке знання російською поетесою не тільки долі Кобзаря, але й культури, історії України. Вона активно використовує українські слова та діалектизми. Образ Т. Шевченка репрезентує особисте, материнське ставлення Є. Полонської до українського поета. Незважаючи на соцреалізм твору, російській поетесі 
вдалося уникнути монументальності в зображенні Т. Шевченка, читач разом 3 автором співчуває головному герою поеми. Перспективи цього дослідження ми бачимо в більш глибокому вивченню репрезентації образу Т. Шевченка в поемі Є. Полонської.

\section{БІБЛІОГРАФІЯ}

Длугач 1937 - Длугач Л. О новых стихах Е. Полонской / Л. Длугач // Литературная газета. - 1937. - 15 июня. - С. 5.

Круглова 2005 - Круглова Т. А. Искусство соцреализма как культурноантропологическая и художественно-коммуникативная система: исторические основания, специфика дискурса и социокультурная роль: автореф. дис. на соиск. уч. степени док. филол. наук : спец. 09.00 .04 «Эстетика» / Т. А. Круглова / Уральский государственный университет им. А. М. Горького. Екатеринбург : Изд-во Уральского государственного университета им. А. М. Горького, 2005. - 27 с.

Полонская 1940 - Полонская Е. Времена мужества. Портрет / Елизавета Полонская. - Л. : Государственное издательство «Художественная литература», 1940. $-80 \mathrm{c}$.

Полонская 2010 - Полонская Е. Стихотворения и поэмы / Е. Полонская. СПб. : Издательство Пушкинского Дома, Издательство ООО «Первый ИПХ», 2010. -384 c.

Фрезинский 2010 - Фрезинский Б. Жизнь и стихи серапионовой сестры Елизаветы Полонской / Б. Фрезинский // Е. Полонская Стихотворения и поэмы. - СПб. : Издательство Пушкинского Дома, Издательство ООО «Первый ИПХ», 2010. - С. 5-75. 